\title{
Brucite in Oceanic Serpentinite
}

\author{
FRIEDER KLEIN ${ }^{1}$, WOLFGANG BACH ${ }^{2}$ AND SUSAN \\ HUMPHRIS $^{1}$
}

${ }^{1}$ Woods Hole Oceanographic Institution

${ }^{2}$ University of Bremen

Presenting Author: fklein@whoi.edu

Brucite formation is believed to play a key role in modulating the $\mathrm{pH}$ and redox conditions during serpentinization. However, recent studies suggested that oceanic serpentinites do not contain significant amounts of brucite[1,2], questioning its importance in serpentinization systems. We applied thermal analysis (TGADSC) and Raman spectroscopy to determine the abundance and distribution of brucite in oceanic serpentinite recovered by drilling $(\mathrm{n}=48)$ and dredging $(\mathrm{n}=22)[3]$. Nearly all $(90 \%)$ of the drilled serpentinites contained brucite, constituting up to 15.6 wt. \% of the altered rock. The range in brucite contents of completely serpentinized peridotites that were recovered by seafloor drilling can be explained by variations of the initial olivine/orthopyroxene ratio of the peridotite protolith, corroborating the idea that $\mathrm{Mg}, \mathrm{Fe}$, and $\mathrm{Si}$ are conserved during serpentinization. In contrast, dredged serpentinites were brucitefree which implies that they lost $\sim 4.0$ wt. $\% \mathrm{MgO}$ on average. Estimated fluxes of $\mathrm{Mg}$ and alkalinity from dissolution of brucite are relatively small on a global scale. Yet, our data suggest that, on average, brucite stores $\sim 20 \%$ of the water in serpentinite uncompromised by weathering, making it one of the most prominent water carriers in slow and ultra-slow spreading oceanic lithosphere. Brucite is common and widespread in unweathered oceanic serpentinite recovered by drilling. This is at odds with the popular notion that oceanic serpentinite is brucitepoor, which likely resulted from a sampling bias toward dredged rocks that had undergone weathering.

References:

[1] Evans \& Frost (2021) Journal of Petrology, doi.org/10.1093/petrology/egab016.

[2] Malvoisin (2015) Earth and Planetary Science Letters 430, $75-85$.

[3] Klein, Humphris, \& Bach (2020) Geochemical Perspectives Letters 16, 1-5. 